Research article

\title{
THE IN VITRO AND IN VIVO ANTI-CANCER POTENTIAL OF MYCOBACTERIUM CELL WALL FRACTION (MCWF) AGAINST CANINE TRANSITIONAL CELL CARCINOMA OF THE URINARY BLADDER
}

\author{
FILION C Mario ${ }^{1}$, RODRIGUES Lucas², JOHANNES Chad ${ }^{3}$, MASIC Aleksandar ${ }^{4 *}$
}

${ }^{1} \mathrm{CNBE} / \mathrm{INRS}$ Institut Armand-Frappier, Laval, QC, H7V 1B7, Canada, ${ }^{2}$ Estima Veterinary Hospital Taubaté - SP, 12020-130, Brazil; ${ }^{3}$ Iowa State University, College of Veterinary Medicine, 1569 LVMC, Ames IA 50011-3619; ${ }^{4}$ Faculty of Ecological Agriculture, Educons University, 21208 Serbia and NovaVive Inc. , Belleville ON K8N 3N2, Canada

(Received 26 May, Accepted 3 September 2017)

\begin{abstract}
Transitional cell carcinoma (TCC), is the most common form of urinary bladder cancer in dogs and represents $2 \%$ of all reported canine cancers. Canine TCC is usually a high-grade invasive cancer and problems associated with TCC include urinary tract obstruction and distant metastases in more than $50 \%$ of affected dogs. TCC is most commonly located in the trigone region of the bladder precluding complete surgical resection. Current treatment options for TCC in dogs include medical therapy, surgery or radiation. Mycobacterium Cell Wall Fraction (MCWF) is a biological immunomodulator derived from non-pathogenic Mycobacterium phlei. MCWF possesses a potential in multiple veterinary areas such as anticancer therapy, palliative care and treatment of infectious diseases in both small and large animals. MCWF is considered a bifunctional anti-cancer agent that induces apoptosis of cancer cells and stimulates cytokine and chemokines synthesis by cells of the immune system. Here we report the results from in vitro and in vivo studies that could suggest use of MCWF as an additional treatment option for TCC in dogs. Particularly, we demonstrated that MCWF induces a concentration dependent inhibition of proliferation of K9TCC cells which was associated with the induction of apoptosis as measured by the proteolytic activation of caspase- 3 and the degradation of PARP. Furthermore, we demonstrated the safety and potential for in vivo MCWF treatment efficacy in dogs bearing stage T2 TCC by reducing clinical signs, and improving the quality of life in dogs with TCC.
\end{abstract}

Key words: canine TCC, MCWF, immunomodulatory

\section{INTRODUCTION}

Urinary bladder cancer accounts for approximately $2 \%$ of all reported malignancies in dogs affecting tens of thousands of dogs worldwide every year [1]. The prevalence of canine bladder cancer in North America, Europe and South America continues to increase despite ongoing research in the prevention and treatment of TCC [2]. *Corresponding author: e-mail: aleksandar.masic@educons.edu.rs 
According to the Veterinary Medical Database (VMDB), dogs with bladder cancer comprised $0.7 \%$ of dogs presenting to university based teaching hospitals [2]. Multiple risk factors contribute to the development of TCC in dogs including exposure to older types of flea control products, lawn chemicals, obesity, sex, and breed [1,3-5]. Invasive TCC is the most common form of canine urinary bladder cancer and the majority of TCCs are categorized as intermediate to high grade papillary infiltrative tumors [6,7]. Other types of bladder tumors occur less frequently and include squamous cell carcinoma, rhabdomyosarcoma, lymphoma, hemangiosarcoma, fibroma and other mesenchymal tumors [6,8]. Canine TCC is often locally advanced at the time of diagnosis thus limiting treatment options, and resulting in poor prognosis and short survival time. According to the World Health Organization (WHO) criteria for staging canine bladder tumors [9] 78\% of dogs with TCC have been staged as T2 tumors (invading the bladder wall), while 20\% were staged as T3 tumors (invading neighboring organs) [10]. TCC is commonly found in the trigonal location and in more than $50 \%$ of dogs involves the urethra which could lead to dysuria and partial or complete obstruction of the urinary tract $[10,11]$. An additional problem for dogs with TCC are the distant metastases seen in approximately $20 \%$ of cases at diagnosis and are associated with poor prognosis [2,11]. Dogs with TCC are also at high risk for the development of secondary urinary tract infections.

Currently, the veterinary oncology standard for the treatment of TCC in dogs is systemic medical therapy comprised of chemotherapy, cyclooxygenase inhibitors or combination of these $[1,10,12]$. Although medical therapy is not usually curative, remission or stable disease can be accomplished with several different drugs $[1,11]$. Surgery as a treatment option for TCC in the urinary bladder is used to obtain the tissue sample for histopathology, to attempt cancer removal from the bladder or to restore urine flow [12]. Radiation could also be used but to a lesser extent due to the complications including cystitis, urinary incontinence, colitis and colonic stricture $[10,12]$.

In the human oncology field, recent interest has focused on the use of mycobacterium cell wall preparations to elicit clinical responses without a number of the undesirable side effects associated with the use of live Mycobacterium bovis strain Bacillus CalmetteGuérin (BCG) which is a standard treatment option for human bladder cancer [1317]. Mycobacterium cell wall fraction (MCWF) is prepared from the non-pathogenic microorganism Mycobacterium phlei [18]. MCWF is considered a bifunctional anticancer agent that induces apoptosis in cancer cells and stimulates cytokine and chemokine synthesis by immune system cells [19].

In the current study, we aimed to demonstrate in vitro and in vivo efficacy for MCWF against canine TCC of the urinary bladder. In addition, preliminary safety information following intravesical administration in dogs was also obtained from a pilot clinical study [20]. Initial laboratory testing was performed with multiple MCWF formulations while in vivo testing was done using commercially available and United States Department 
of Agriculture (USDA) and Canadian Food Inspection Agency (CFIA) fully licensed MCWF preparation for veterinary use (Immunocidin ${ }^{\circledR}$, NovaVive, Canada).

\section{MATERIALS AND METHODS}

\section{Cells}

K9TCC, a canine transitional carcinoma cancer cell line of the urinary bladder, (kindly provided by Dr. Deborah Knapp, Department of Veterinary Clinical Sciences, School of Veterinary Medicine, Purdue University, West Lafayette, IN, USA) was utilized. Cells were maintained in DMEM containing 10\% Fetal Bovine Serum (FBS) (both from Wisent, St-Bruno, Quebec, Canada) and $10.0 \mu \mathrm{g} / \mathrm{mL}$ gentamycin sulphate (Sigma-Aldrich, Oakville, Ontario, Canada).

\section{Mycobacterium Cell Wall Fraction (MCWF)}

Four different MCWF formulations were prepared for the in vitro study purpose; MCWF suspension in water for injection, MCWF emulsion, MCWF in phosphate buffered saline and MCWF in hyaluronic acid. In addition, vehicle controls for water for injection (WFI), phosphate buffered saline (PBS), hyaluronic acid (HA) and emulsion were prepared and used in this study. The control emulsion consisted of $2.0 \% \mathrm{v} / \mathrm{v}$ squalene and $0.2 \% \mathrm{v} / \mathrm{v}$ Tween 8 . The MCWF formulation used for the in vivo portion of the study was commercially available and USDA and CFIA fully licensed veterinary product Immunocidin ${ }^{\circledR}$ (NovaVive Inc. Canada) indicated for the treatment of mixed mammary tumors and mammary adenocarcinoma in dogs.

\section{Inhibition of proliferation}

K9TCC cells were seeded at density of $0.5 \times 10^{5}$ cells $/ \mathrm{mL}$ in 96-well flat-bottomed microplates and incubated at $37^{\circ} \mathrm{C}$ and $5 \% \mathrm{CO}_{2}$. K9TCC cells were treated with: $0.1,1$, 10 and $100 \mu \mathrm{g} / \mathrm{mL}$ of each formulation of MCWF for 72 hours. Cellular proliferation was measured by determination of dimethyl-thiazol-diphenyl-tetrazolium-bromide (MTT) reduction as described elsewhere [21]. Briefly, $100 \mu \mathrm{L}$ of MTT (Ameresco, Solon, OH, USA) was dissolved in PBS at concentration of $5 \mathrm{mg} / \mathrm{mL}$ and added to the each well. Plates were incubated at $37^{\circ} \mathrm{C}$ in an atmosphere of $5 \% \mathrm{CO}_{2}$ for 4 hours. At the end of incubation period, acid-isopropanol $(1.0 \mathrm{~mL}$ of $0.04 \mathrm{~N}$ hydrochloric acid in isopropanol) was added to the wells, and reduced MTT was measured at a wavelength of $570 \mathrm{~nm}$.

\section{Exposure time analysis}

Cells were seeded at $0.5 \times 10^{5}$ cells $/ \mathrm{mL}$ in 96-well flat-bottomed microplates and treated with $0.1,1,10$ and $100 \mu \mathrm{g} / \mathrm{mL}$ of MCWF in WFI for 30 minutes, 1, 3, 24 and 72 hours. Cells were washed five times with PBS at the indicated time points to remove 
unbound MCWF and incubated for a total of 72 hours in complete DMEM medium. Cellular proliferation was measured by MTT reduction as described above.

\section{Apoptosis detection}

K9TCC cells were incubated at $1 \times 10^{5}$ cells $/ \mathrm{ml}$ in 6 -well flat-bottomed microplates with $100.0 \mu \mathrm{g} / \mathrm{ml}$ of MCWF in WFI. The active form of caspase-3 (17 kDa fragments) and cleaved poly-ADP ribose polymerase (PARP) $(85 \mathrm{kDa}$ fragments) were detected by flow cytometry in K9TCC cells after 72 hours of incubation. K9TCC cells were collected, washed twice with PBS and fixed in cold $0.25 \%$ paraformaldehyde for 30 minutes at $4^{\circ} \mathrm{C}$. The fixed cells were permeabilized after washing with PBS containing $0.05 \%$ Tween 20 and $1 \%$ FBS for 15 minutes at $37^{\circ} \mathrm{C}$. Cells were then washed twice by centrifugation with PBS-1\% FBS and labeled with a PE-conjugated antibody recognizing the active form of caspase-3 (clone C92-605, BD Bioscience) or a FITC-conjugated antibody recognizing a degradation product of PARP (clone 214/216, Biosource, Camarillo. CA, USA) for 30 minutes at $4^{\circ} \mathrm{C}$. Flow cytometry was carried out on a FACSCalibur (BD Bioscience) and data analysis was carried out using CELLQuest software.

\section{Combination of MCWF with piroxicam}

Piroxicam (BioMol Research, Plymouth Meeting, PA, USA) was prepared in DMSO at $25 \mathrm{mg} / \mathrm{mL}$. The inhibition of proliferation and induction of apoptosis were monitored by flow cytometry as described above. Briefly, 1 × $10^{5} \mathrm{~K} 9 \mathrm{TCC}$ cells $/ \mathrm{mL}$ were incubated in 6-well flat-bottomed microplates at $37^{\circ} \mathrm{C}$ in an atmosphere of $5 \%$ $\mathrm{CO}_{2}$ with $100 \mu \mathrm{g} / \mathrm{mL} \mathrm{MCWF} \pm 0.1,0.5$ and $1.0 \mu \mathrm{M}$ piroxicam, or corresponding volumes of DMSO (vehicle control). The proteolytic activation of caspase- 3 and the degradation of PARP were monitored by flow cytometry as described above following incubation for 72 hours.

\section{Pilot clinical study}

\section{Patient Recruitment and Screening Evaluations}

Preliminary data on the safety and efficacy of MCWF instilled in the bladder after dilution in saline was performed at a single veterinary site in Brazil (Estima Veterinary Hospital, Taubaté, Brazil). An experimental study protocol (protocol \# BNC01082011-CCAU) was developed in accordance with the Canadian Council on Animal Care (CCAC), and was reviewed and approved by the research ethics committee at the participating site. Signed informed consent was obtained from the owners whose dogs were recruited for the study. Dogs with histologically confirmed TCC were completely staged using 3 view thoracic radiographs and abdominal ultrasound. Inclusion criteria allowed enrolment of the dogs with tumor recurrence following surgery and/ 
or chemotherapy or when owners declined standard treatment. Dogs with distant metastasis or in regional lymph nodes were excluded from this study.

\section{Treatment procedures}

MCWF emulsion (Immunocidin ${ }^{\circledR}$ ) was supplied by NovaVive Inc., Canada. Each vial of MCWF Immunocidin ${ }^{\circledR}$ contained $2.5 \mathrm{~mL}$ of MCWF formulated as a triphasic water/oil/water emulsion consisting of phosphate buffered saline and adjuvanted with squalene. MCWF emulsion (1.5-2.5mL; Table 2.) was diluted to a final volume of $10 \mathrm{~mL}$ in sterile $0.9 \% \mathrm{NaCl}$ and instilled into the empty bladder via urethral catheter. MCWF was left in the bladder for 60 minutes, turning the dog on each side every 30 minutes to assure sufficient contact time with the bladder mucosal surface and tumor. No sedation or anesthetic procedures were used for the purpose of MCWF administration. The induction phase consisted of four weekly instillations ( $3 \mathrm{dogs}$ ) or 3 consecutive daily instillations ( 2 dogs). Following the induction phase MCWF was administered every other week four times (maintenance phase), and then once every 28-30 days (follow-up phase). (Figure 1).
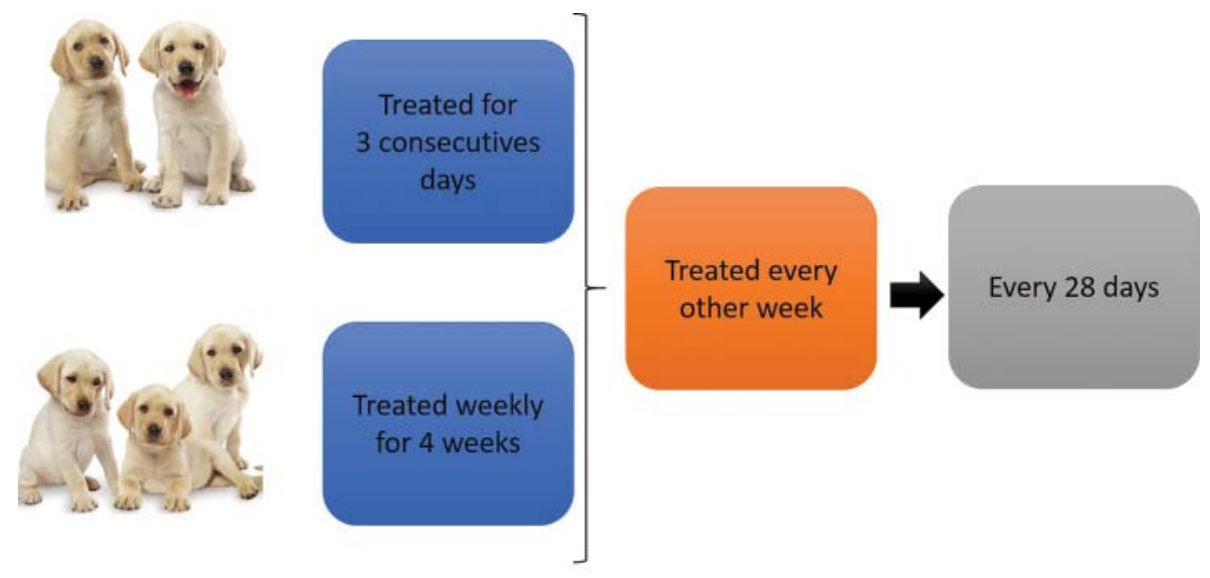

Induction Phase

Maintenance Phase (Four (4) bi-weekly treatments)

Follow-up Phase

Figure 1. Pilot clinical study design and treatment regimen

\section{Safety Evaluation}

Complete clinical history, physical examination, $\mathrm{CBC}$, biochemistry and urinalysis were collected at baseline and at four weeks intervals. Dogs were evaluated for adverse events daily by their owners, and every other week in the clinic before and following MCWF treatment. Adverse events were monitored, classified and reported according to Veterinary Co-operative Oncology Group - Common Terminology Criteria for Adverse Events (VCOG-CTCAE)] [22]. Parameters assessed included but were not 
limited to clinical hematology, biochemistry, gastrointestinal, metabolic, pain, renal and genitourinary changes [23].

\section{Evaluation of Response}

Evaluation of the MCWF in vivo treatment efficacy was determined based on tumor measurements, clinical observations and quality of life assessment (modified questionnaire from Lynch et al.) [24] performed every 4 weeks. Tumor response was evaluated using 2-D abdominal ultrasound after bladder distension with $5 \mathrm{~mL} / \mathrm{kg}$ of saline every four weeks of treatment [25]. If a biological response was not seen at the time of the second evaluation (8 weeks), MCWF therapy was discontinued and an alternative treatment was provided at the discretion of the investigator following approval from the dog owner. A complete response (CR) was defined as disappearance of all of the clinical signs and observed target lesions. Partial response (PR) was defined as $>30 \%$ reduction of the longest diameter of the target lesion. Progressive disease (PD) was defined as for $>20 \%$ increase in the size of the longest target lesion, and stable disease was defined by the absence of criteria for either a response or progression [26].

\section{RESULTS}

\section{Inhibition of proliferation}

Four different formulations of MCWF were evaluated for their ability to inhibit the proliferation of K9 TCC cells: MCWF in WFI, MCWF emulsion, MCWF with HA and MCWF in PBS. As shown in Figure 1, MCWF has the ability to inhibit the proliferation of K9 TCC cells in a concentration dependent manner, the maximal inhibitory activity being approximately $45 \%$ at $1-100 \mu \mathrm{g} / \mathrm{mL}$ MCWF. No significant difference in activity was observed between the four MCWF formulations tested (Figure 2). Since the four formulations gave similar inhibitory results, MCWF in WFI was used for further in vitro study analysis due to the minimal cell cytotoxicity.

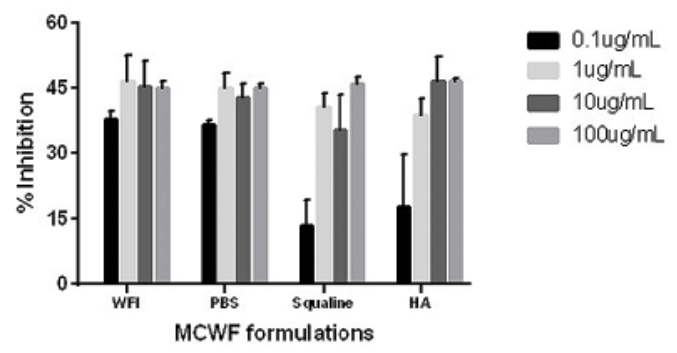

Figure 2. In vitro inhibitory activity of MCC against K9TCC cells (\% inhibition).

Results are expressed as the percent inhibition in comparison to untreated cells (means \pm S.D; $(n=6)$ ). The vehicle controls (emulsion, HA, PBS and WFI) gave less than $3 \%$ inhibition (data not plotted). Percent inhibition was statistically significant 


\section{Exposure time}

The minimum exposure time required for maximal anticancer activity of MCWF in K9TCC cell line was also determined. K9TCC cells were incubated with MCWF for 30 minutes, 1, 3, 24 or 72 hours, and inhibitory activity was determined at 72 hours total incubation time. The results show that incubation of K9TCC cells with MCWF at concentrations $>10 \mu \mathrm{g} / \mathrm{mL}$ for 30 minutes results in an inhibition of proliferation identical to that observed when cells were incubated with $>10 \mu \mathrm{g} / \mathrm{mL}$ MCWF for 72 hours (Figure 3). These results suggest that MCWF interacts rapidly with canine bladder cancer cells. Thirty minutes of exposure time is sufficient for maximal expression of the anticancer activity of MCWF at concentrations $>10 \mu \mathrm{g} / \mathrm{mL}$. The retention of MCWF within the canine bladder for 30 minutes may therefore be sufficient for an efficient and optimal induction of anticancer activity in dogs with bladder cancer.

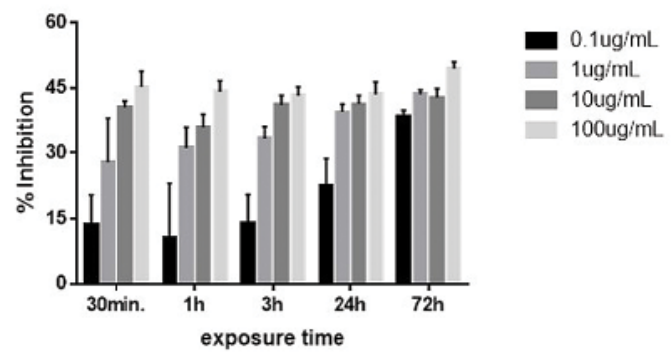

Figure3.The effect of exposure time on the in vitro inhibitory activity of MCWF against K9TCC cells (\% inhibition). Results are expressed as the percentage inhibition in comparison to untreated cells (mean \pm S.D; $(n=4)$ ).

\section{Induction of apoptosis}

One of the mechanisms whereby MCWF inhibits proliferation of K9TCC cells could be through the induction of apoptosis. The effect of MCWF on the proteolytic activation of cysteinyl aspartate-specific proteinases-3 (caspase-3) and the cleavage of poly [ADP-ribose] polymerase (PARP), two critical and irreversible steps in apoptosis, was investigated. The proteolytic activation of procaspase-3 in K9TCC cells was evaluated by flow cytometry using a PE-conjugated antibody recognizing solely the active form of the caspase-3. Incubation of K9TCC cells with $100 \mu \mathrm{g} / \mathrm{mL} \mathrm{MCWF}$ in WFI for 72 hours resulted in a significant increase in the level of active caspase-3 fragments into the cytosol of the K9TCC cells (Figure 4). The cleavage of PARP, a key enzyme activated by DNA breaks and a substrate for caspase-3, is required for the execution of apoptosis. PARP was found to be cleaved in K9TCC cells following treatment with $100 \mu \mathrm{g} / \mathrm{mL}$ MCWF in WFI (Figure 4) as measured by flow cytometry using a FITC-conjugated antibody recognizing the degradation product of PARP. The activation of caspase-3 and the degradation of PARP following treatment of K9TCC cells with MCWF indicated that MCWF has the capacity to induce apoptosis in this canine cancer cell line. 


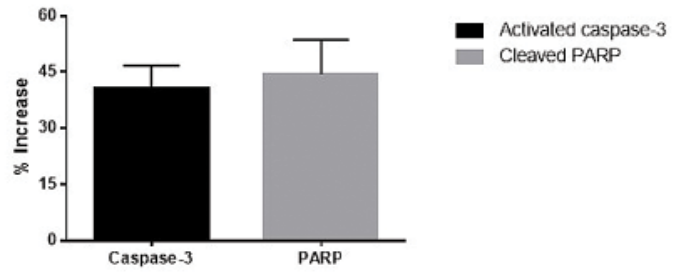

Figure 4. Induction of apoptosis in K9TCC cells. The activation of caspase-3 and degradation of PARP in K9 TCC cells by MCWF following incubation with $100 \mu \mathrm{g} / \mathrm{ml}$ for 72 hours. Results are expressed as the percentage increase compared to untreated K9TCC cells. The results shown are the means \pm SD of three independent experiments $(n=3)$.

\section{Anticancer activity of MCWF combined with piroxicam}

Piroxicam, a Non-Steroidal Anti-inflammatory Drug (NSAID), has been routinely used in veterinary clinics as a conservative approach to TCC treatment providing both anti-cancer and palliative effects. The apoptosis-inducing activity of MCWF in combination with piroxicam in the K9TCC cell line was further examined. The results from our study showed that MCWF and piroxicam act synergistically with piroxicam potentiating the apoptotic activity of MCWF [27]. The addition of $0.01,0.1$ or $1 \mu \mathrm{M}$ of piroxicam was found to increase the percentage of activated caspase-3 (Figure 5a) and cleaved PARP (Figure 5b) in K9TCC cells.
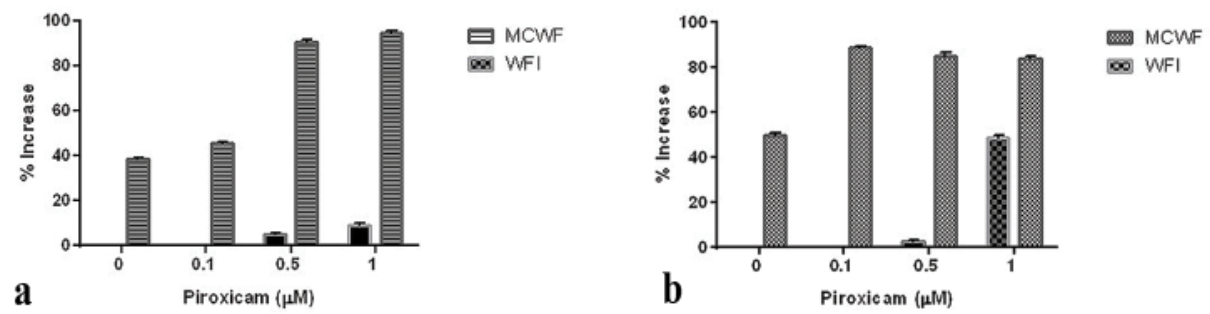

Figure 5 (a). MCWF induction of apoptosis in K9TCC cells in combination with piroxicam. The activation of caspase- 3 in K9TCC cells treated with piroxicam and MCWF $(100 \mu \mathrm{g} / \mathrm{mL}$ $\mathrm{MCWF} \pm 0.1,0.5$ and $1 \mu \mathrm{M}$ piroxicam for 72 hours). Results are expressed as the percentage increase in activated caspase-3 compared to untreated K9 TCC cells (means \pm SD; $(n=2)$ ). Minimal activity, $<2 \%$, was observed with DMSO alone (vehicle control) at the highest concentration tested (equivalent to $0.13 \% \mathrm{v} / \mathrm{v}$ DMSO). (b). MCWF induction of apoptosis in K9TCC cells in combination with piroxicam (\% degradation of PARP). The degradation of PARP in K9TCC cells treated with piroxicam and MCWF $(100 \mu \mathrm{g} / \mathrm{mL}$ MCWF $\pm 0.1,0.5$ and $1 \mu \mathrm{M}$ piroxicam for 72 hours). Results are expressed as the percentage increase in cleaved PARP compared to untreated K9TCC cells. (means \pm SD; $(n=2)$ ). Minimal activity, less than 3\%, was observed with DMSO alone (vehicle control) at the highest concentration tested (equivalent to $0.13 \% \mathrm{v} / \mathrm{v} \mathrm{DMSO})$.

\section{Clinical efficacy and Safety after MCWF treatment}

During the period of September 2013-January 2016, a total of five dogs, four females and one male, 9-13 years of age (Table 1) were treated for TCC with MCWF (Immunocidin ${ }^{\circledR}$ ). Dogs were diagnosed based on tumor biopsy and staged 
by abdominal ultrasound and thoracic imagining. All dogs were staged as T2N0M0. The clinical signs common for patients diagnosed with TCC as dysuria, pollakiuria, and hematuria were reported at initial visit (Table 2). During the initial physical examinations, all dogs were presented with good health, body score 3-5 on 9-point scale and without clinically significant abnormalities in complete blood cell counts (CBC) and clinical biochemistry. Two dogs were diagnosed with stage three chronic kidney disease with creatinine levels at 2.4 and $2.8 \mathrm{mg} / \mathrm{dL}$. Both dogs remained in the study as no other clinical signs were shown and they were in good health, and lacking other treatment options. Four dogs had tumors that were unresectable and their owners declined standard treatment protocols or had previous surgery and failed to respond to chemotherapy (one dog) (Table 1). Initial MCWF treatment protocol included three consecutive daily administrations of MCWF (Immunocidin ${ }^{\circledR}$. NovaVive, Canada) directly into the bladder via urethral catheter, followed by four bi-weekly treatments and then once every 28 days (two dogs). Due to the difficulty for the owners to comply with daily administrations, the treatment protocol was modified so the next three dogs received MCWF intravesically four times once a week, followed by four bi-weekly treatments and then once every 28 days. Two patients had a complete resolution of characteristic TCC clinical signs such as dysuria and significant reduction of clinical symptoms was observed in the remaining three dogs. Pollakiuria was completely resolved in four dogs following first treatment while hematuria was completely resolved in one patient, with significant reduction in other four dogs (Table 2.). Tumor measurements using $2 \mathrm{D}$-abdominal ultrasound [25] performed every four weeks revealed variable tumor responses with partial response observed in one dog (Figure $6(\mathrm{a}-\mathrm{c})$ ) and stable disease in four dogs (Table 3; Figure $6(\mathrm{~d}-\mathrm{g})$ ) [20]. One dog failed to concur with the treatment protocol and the patient showed signs of advanced disease following the fifth MCWF treatment and was removed from the future treatments. In addition, one dog was removed from the study due to the owner's decision following the fifth MCWF treatment. The remaining three dogs maintained the SD for 9, 18 and 21 months and had survival times of 11, 20 and 46 months respectively (Table 3; Figure 7) [20]. Hematology results showed that there were no clinically relevant abnormalities induced by MCWF administration (data not shown). One animal developed mild transient hematuria following the third MCWF treatment but there was no requirement for hospitalization or other treatments.

Table 1. Demographics of dogs included in the study and therapy prior to enrollment

\begin{tabular}{ccccl}
\hline Patient & Breed & Age (years) & Gender & Previous Treatment \\
\hline 1 & Brazilian Terrier & 13 & Male & Surgery, Carboplatinum, Doxorubicin \\
\hline 2 & Beagle & 9 & Female & Non-resectable, denied chemotherapy \\
3 & Poodle & 11 & Female & Non-resectable, Mitoxantrone AE's \\
4 & Poodle & 13 & Female & Non-resectable, denied chemotherapy \\
5 & Pit Bull & 13 & Female & Non-resectable, denied chemotherapy \\
\hline
\end{tabular}


Table 2. TCC Clinical signs during induction phase of MCWF treatment

\begin{tabular}{lccccc}
\hline Clinical sign & Patient $\mathbf{1}$ & Patient 2 & Patient 3 & Patient 4 & Patient 5 \\
\hline Dysuria & Reduction & Reduction & Reduction & Resolution & Resolution \\
Hematuria & Reduction & Reduction & Reduction & Resolution & Reduction \\
Pollakiuria & Resolution & Resolution & Reduction & Resolution & Resolution \\
Fever & none & none & none & none & none \\
Anorexia & none & none & none & none & none \\
Weight Loss & none & none & none & none & none \\
Vomiting & none & none & none & none & none \\
Diarrhea & none & none & none & none & none \\
Hematology & none & none & none & none & none \\
Renal/Hepatic & none & none & none & none & none \\
\hline
\end{tabular}

Table 3. Clinical effectiveness of MCWF following intravesical treatment

\begin{tabular}{ccccc}
\hline $\begin{array}{c}\text { Patient } \\
\#\end{array}$ & $\begin{array}{c}\text { \# of } \\
\text { Treatments }\end{array}$ & Tumor Response /Duration & Clinical Status & Survival time \\
\hline 1 & 19 & PR, SD (21 months) & In treatment, alive & 46 months \\
2 & 5 & SD (2 months) and PD & $\begin{array}{c}\text { Treatment interruption, and } \\
\text { progressive disease }\end{array}$ & Not available \\
3 & 16 & SD (9 months), and PD & Treated with mitoxantrone & 11 months \\
4 & 16 & SD (18 months) & In treatment, alive & 20 months \\
5 & 5 & $\begin{array}{c}\text { SD (induction phase), the owner } \\
\text { declined further treatment }\end{array}$ & $\begin{array}{c}\text { Treatment interruption, } \\
\text { alive }\end{array}$ & Not available \\
\hline
\end{tabular}

There were no other clinically significant observed adverse events in dogs treated with MCWF during the observation period. Furthermore, assessment of the quality of life questionnaire provided to the owners showed that there was improvement in quality of life of the TCC patients receiving MCWF as determined based on the reduced urinary accidents, increased playfulness, responsiveness and general health [20]. 

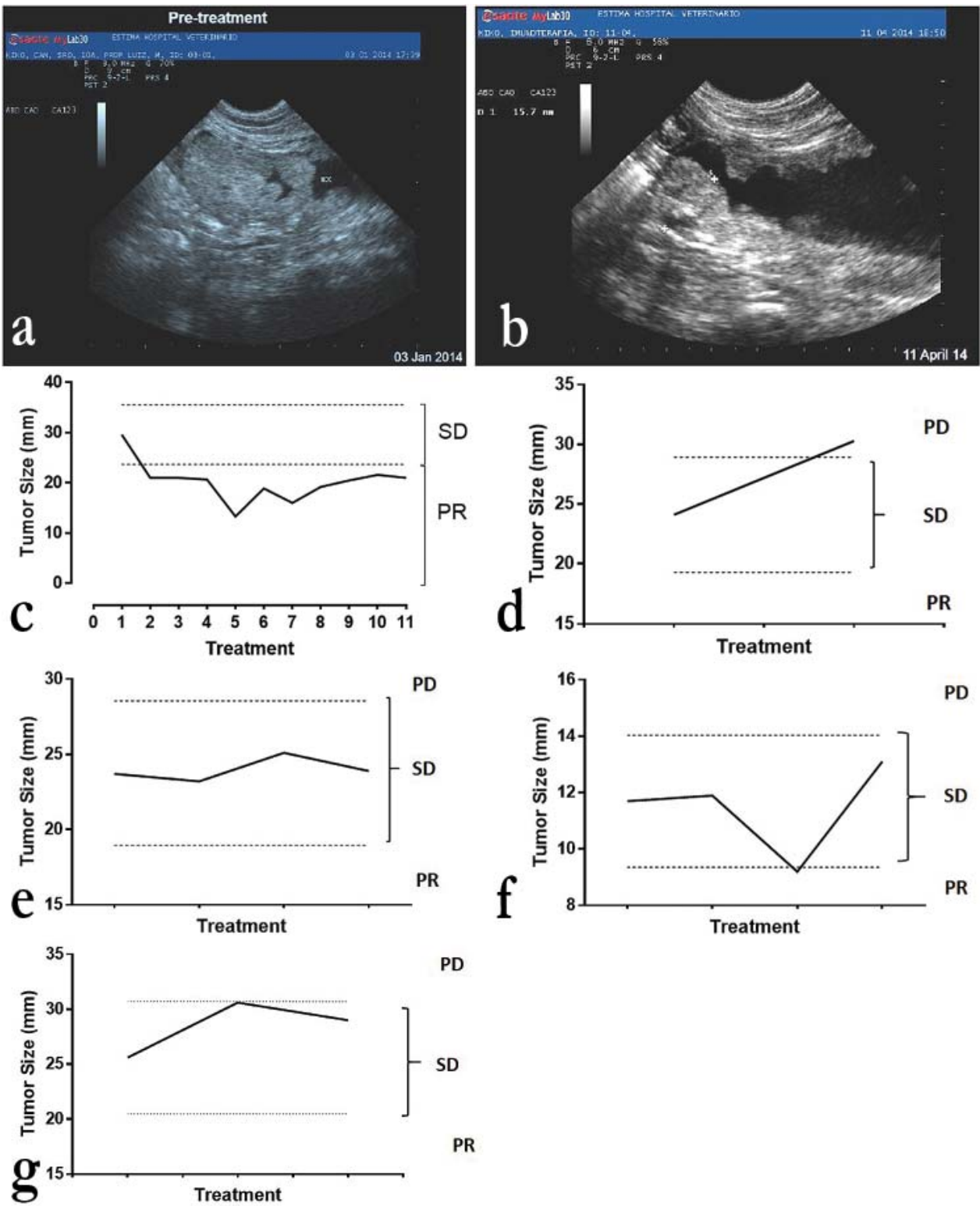

Figure 6. Tumor response in patient \#1; Ultrasound images at pre-treatment (a) and following the fifth treatment PR (b); tumor response measurements following each assessment (c). Tumor size presented as longest diameter determined by ultrasound, Vertical dotted line presents end of induction phase.. Tumor responses for patients \#2 (d), \#3 (e), \#4 (f) and \#5 (g) following MCWF induction phase 


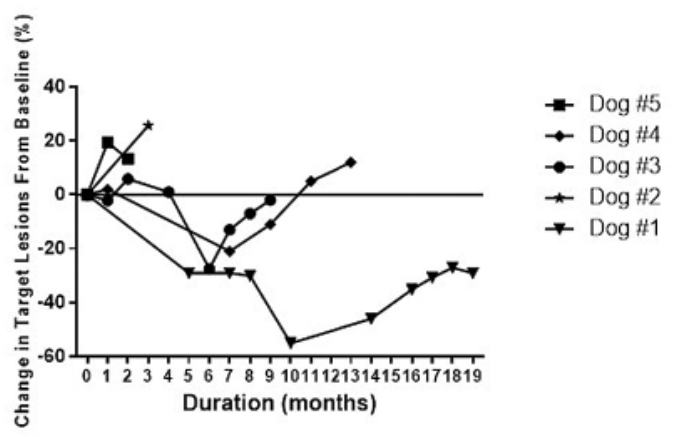

Figure 7. Change in Target lesion (\%) from the baseline since the time (months) of treatment with MCWF. Range of q28 treatments was 2-11

\section{DISCUSSION}

Urinary bladder tumors account for approximately $2 \%$ of all canine tumors and transitional cell carcinoma (TCC) is the most common form, affecting close to 20,000 dogs each year in the US alone [2]. Canine TCC closely resembles high-grade, muscleinvasive TCC in humans, making it a relevant animal model for transitional research $[1,7]$. Although progress has been made in the treatment of TCC, a significant number of affected dogs succumb to the disease each year. There are multiple challenges in regards to invasive urinary bladder cancer, therefore, current research is focused on improving methods of prevention, early detection and treatment of both primary and metastatic disease [10].

One of the novel strategies for the treatment of cancer in both humans and companion animals is directed towards the development of specific and non-specific immunotherapies. Mycobacterium Cell Wall Fraction (MCWF) is a biological immunomodulator derived from non-pathogenic Mycobacterium phlei [19]. MCWF possesses potential in multiple veterinary areas such as anticancer therapy and treatment of infectious diseases in both small and large animals [28-30]. Data from preclinical studies have shown that MCWF is a bifunctional agent with immune stimulatory and direct anticancer activity [19,29]. The immunomodulatory and anti-cancer activity of MCWF is attributed to the presence of chemical entities such as muramyl-dipeptide (MDP), trehelose dimycolate, lipoarabinomannan, lipoteichoic acid, peptidoglycan and glycan [19]. In addition to the cell wall chemical components mycobacterial DNA is preserved and complexed to the cell wall fragments. DNA present in MCWF appears to be responsible for both chemotherapeutic (anti-cancer) and immunomodulatory activities [29]. MCWF induce production of cytokines by different immune effector cells [19]. Furthermore, the subcutaneous (SC), intraperitoneal (IP) or intravenous (IV) administration of MCWF resulted in the synthesis of IL-6, IL-8, IL-12, IL-18 and TNF- $\alpha$ in dose dependent manner [29] in mouse models. An elevation of IL6, IL-8, IL-12 and IL-18 cytokines following intravesical MCWF administration in human patients with carcinoma in situ (CIS) of the bladder has been demonstrated 
$[19,31]$. The synthesis of significant amounts of IL-12 and IL-18 following topical administration of MCWF is of particular interest since these cytokines are known to possess potent anti-cancer activity following systemic or local administration [32]. Clinical evaluation of MCWF, formulated as an oil in water emulsion in the treatment of human patients with CIS of the bladder, demonstrated anticancer activity in conjunction with a satisfactory safety profile [16]. CWF was administered intravesically in humans using an MCWF emulsion formulation and resulted in recurrence-free survival rates of $62.5 \%$ at 12 weeks, $49.3 \%$ at 24 weeks, and $41.1 \%$ at 60 weeks [14]. Similarly, MCWF has been shown to have anticancer activity in an animal model of bladder cancer as well [15]. Therefore, our goal was to further investigate the MCWF application in canine TCC treatment by assessing the mode of action (inhibition of proliferation, apoptosis, exposure time), safety and efficacy against TCC both in vitro and in vivo.

The ability of MCWF to induce apoptosis in a number of types of human cancer cells under in vitro and in vivo conditions has already been demonstrated [14,15,29]. The ability of MCWF to induce apoptosis in K9TCC cells was determined by assessing MCWF ability to trigger proteolytic activation of cysteinyl aspartate-specific proteinases-3 (caspase 3) and the cleavage of poly [ADP-ribose] polymerase (PARP), two crucial and irreversible steps in apoptosis. Caspase- 3 has been classified as an executioner of apoptosis due to its capacity to cleave crucial substrates including PARP. Here, we reported the significant increase in the level of active caspase- 3 fragments and PARP into the cytosol of the K9TCC cells following treatment with MCWF. The activation of caspase- 3 and the degradation of PARP following treatment of K9TCC cells with MCWF demonstrated that MCWF has the capacity to induce apoptosis in this canine cancer cell line. These observations supported the perceived efficacy and proposed mode of action on the inhibition of proliferation of K9TCC cell line reported above. Induction of apoptosis is also supported by the results from current pilot clinical study that showed partial remission or induction of stabile disease following the induction phase [20].

MCWF has been found to induce cell cycle arrest at the G0/G1 phase in a number of human and murine cancer cell lines. The cell cycle arrest induced by MCWF was found to be transient peaking after 24 hours of incubation $[31,33]$. We also examined the effect of MCWF on cell cycle progression of K9TCC cells following their exposure to MCWF and flow cytometry analysis. The results showed that MCWF had no specific cell cycle arresting effect on K9TCC cells activity after 24 or 48 hours of incubation with MCWF (data not shown).

Application of non-selective cyclooxygenase inhibitors is commonly used as conservative type of treatment providing limited anti-cancer effect and excellent palliative effect thus improving quality of life of dogs with TCC $[2,23,34]$. Therefore, we tested in vitro the anti-cancer activity of piroxicam the most commonly used COX inhibitor in dogs with TCC, in combination with MCWF. Our data showed that there is a clear synergistic anti-cancer effect on the K9TCC cell line following exposure 
to MCWF in combination with piroxicam. It was demonstrated that piroxicam potentiated the apoptotic activity of MCWF leading to an increased percentage of activated caspase-3 and cleaved PARP in K9TCC cells thus resulting in more rapid apoptosis of cancer cells.

Drug retention following intravesical administration is one of the limiting factors for the treatment of bladder cancer. The retention time for many drugs in the human bladder is usually short (less than 2 hours) and may be less than optimal. One of the challenges for use of MCWF in a clinical setting as a treatment option for canine TCC of the bladder is establishing adequate exposure time, sufficient to provide desirable efficacy and limiting any side effects. Our results from in vitro experiments suggested that MCWF interacts rapidly with canine bladder cancer cells following direct exposure. It is shown that thirty (30) minutes exposure time was sufficient for maximal expression of the anticancer activity of MCWF at concentrations $>10.0 \mu \mathrm{g} /$ $\mathrm{ml}$. The retention of MCWF within the canine bladder for 30 minutes may therefore be sufficient for an efficient and optimal induction of anticancer activity in dogs with bladder cancer following topical administration. In addition, data from the pilot clinical study also supported previous observation as no clinically significant adverse effects were observed while improvement in clinical signs and tumor reduction were observed. Furthermore, no special requirements in terms of sedation or anesthesia and relatively short procedure suggest MCWF treatment is a feasible and inexpensive approach that could be easily performed in both specialty and primary care veterinary practices.

Previous clinical experience with MCWF emulsion in humans showed clinical effectiveness in the treatment of patients with CIS of the bladder who were treatment naive or in whom BCG treatment had failed [13,14,16]. The small pilot clinical study was designed to address the clinical safety and effectiveness of the same MCWF composition, formulated as an emulsion, for the treatment of TCC in dogs. The patient population used, consisted primarily of dogs whose owners declined standard treatment or previous treatments failed. Despite the small number of patients, the results of the study suggested that MCWF has safety and potential efficacy when used to treat patients with TCC of the bladder in whom previous therapy failed or who were treatment naïve. Although encouraging, these results are preliminary and the sample size is small. Further studies are needed to better define the clinical safety and efficacy of MCWF in TCC patients. MCWF has also been evaluated in Phase II and III clinical trials as an intravesical treatment for non-muscle invasive bladder cancer in humans, specifically in patients who failed or become refractory to BCG treatment and/or chemotherapy. These studies demonstrated significantly decreased side effects and improved quality of life [13].

In summary, results from the current study demonstrated that MCWF causes a concentration-dependent inhibition of proliferation of K9TCC cells that was associated with the induction of apoptosis, as measured by the proteolytic activation of caspase- 3 and the degradation of PARP. The inhibition of proliferation and apoptosis 
inducing activities of MCWF appear to be independent of any phase-specific cell cycle arrest in K9 TCC cells. MCWF requires a short incubation time for maximal activity both in vitro and in vivo. An exposure period of 30 minutes appears to be sufficient for optimal activity of MCWF against K9TCC cells. The retention of MCWF within the bladder for 30 minutes may therefore be sufficient for an optimal induction of anticancer activity in dogs with bladder cancer. These preliminary results show that MCWF has potential in the treatment of canine bladder cancers by inducing apoptosis of cancer cells. The known ability of MCWF to induce synthesis of cytokines by canine immune cells may also contribute to the potential of MCWF for the treatment of canine bladder cancer. No treatment-limiting toxicity has been noted with the intravesical use of MCWF in dogs with TCC.

There are several benefits from the use of MCWF in canine TCC patients. The combination of chemotherapeutic-like (apoptosis) and immunotherapeutic (cytokine induction) activities in MCWF is unique and distinguishes it from other classical cancer treatments such as chemotherapy. In addition, the chemotherapeutic-like activity of MCWF appears to be independent of the presence of the multiple drug resistance (atypical or typical) Fas-ligand resistance or p53, p-21 and p-16 mutations, all of which affect the activity of a number of classical chemotherapeutic drugs [19]. There are no restrictions involving the preparation and disposal of the agent, in contrast to requirements for the use of BCG or chemotherapeutic agents. In addition, there is no requirement for biohazard precautions during the preparation and disposal of the agent. MCWF emulsion was well tolerated, and the number and severity of treatment limiting AEs were clearly lower than those typically seen with the use of BCG or chemotherapy $[13,14]$. Based on the above reported observations from in vitro and in vivo studies indicating biological activity against canine TCC, further prospective studies investigating use as an alternative or additional treatment option for canine TCC are warranted.

\section{Authors' contributions}

FC designed and carried out all in vitro experiments and helped to draft the manuscript. RL designed and carried out the in vivo portion of the study, analysed data and participated in manuscript writing. JC participated in the in vivo study design, data analysis and manuscript writing. MA participated in the design of in vivo portion of the study, performed the data analysis and drafted the manuscript. All authors read and approved the final manuscript.

\section{Declaration of conflicting interests}

FCM and MA are former or current employees of the company holding licensing and distribution rights for Immunocidin. RL and JC are scientific consultants occasionally receive honorarium for their services. 


\section{REFERENCES}

1. Mutsaers AJ, Widmer WR, Knapp DW. Canine transitional cell carcinoma. J Vet Intern Med. 2003;17: 136-144.

2. Knapp DW, Ramos-Vara JA, Moore GE, Dhawan D, Bonney PL, Young KE. Urinary bladder cancer in dogs, a naturally occurring model for cancer biology and drug development. ILAR J. 2014;55: 100-118.

3. Raghavan M, Knapp DW, Bonney PL, Dawson MH, Glickman LT. Evaluation of the effect of dietary vegetable consumption on reducing risk of transitional cell carcinoma of the urinary bladder in Scottish Terriers. J Am Vet Med Assoc. 2005;227: 94-100.

4. Raghavan M, Knapp DW, Dawson MH, Bonney PL, Glickman LT. Topical flea and tick pesticides and the risk of transitional cell carcinoma of the urinary bladder in Scottish Terriers. J Am Vet Med Assoc. 2004;225: 389-394.

5. Glickman LT, Raghavan M, Knapp DW, Bonney PL, Dawson MH. Herbicide exposure and the risk of transitional cell carcinoma of the urinary bladder in Scottish Terriers. J Am Vet Med Assoc. 2004;224: 1290-1297.

6. Withrow SJ, Vail DM, Page RL. Small Animal Clinical Oncology. In: Knapp DW, McMillan SK, editors. Tumors of the urinary System: Elsevier, 2013.

7. Knapp DW, Glickman NW, Denicola DB, Bonney PL, Lin TL, Glickman LT. Naturallyoccurring canine transitional cell carcinoma of the urinary bladder A relevant model of human invasive bladder cancer. Urol Oncol. 2000;5: 47-59.

8. Valli VE, Norris A, Jacobs RM, Laing E, Withrow S, Macy D, Tomlinson J, McCaw D, Ogilvie GK, Pidgeon G, Henderson RA. Pathology of canine bladder and urethral cancer and correlation with tumour progression and survival. J Comp Pathol. 1995;113: 113-130.

9. L.N. O. TNM Classification of Tumors in Domestic Animals. In: WHO, editor. Geneva: World Health Organization (WHO), 1980.

10. Fulkerson CM, Knapp DW. Management of transitional cell carcinoma of the urinary bladder in dogs: a review. Vet J. 2015;205: 217-225.

11. Knapp DW, Henry CJ, Widmer WR, Tan KM, Moore GE, Ramos-Vara JA, Lucroy MD, Greenberg CB, Greene SN, Abbo AH, Hanson PD, Alva R, Bonney PL. Randomized trial of cisplatin versus firocoxib versus cisplatin/firocoxib in dogs with transitional cell carcinoma of the urinary bladder. J Vet Intern Med. 2013;27: 126-133.

12. Cannon CM, Allstadt SD. Lower urinary tract cancer. Vet Clin North Am Small Anim Pract. 2015;45: 807-824.

13. Morales A, Cohen Z. Mycobacterium phlei cell wall-nucleic acid complex in the treatment of nonmuscle invasive bladder cancer unresponsive to bacillus Calmette-Guerin. Expert Opin Biol Ther. 2016;16: 273-283.

14. Morales A, Phadke K, Steinhoff G. Intravesical mycobacterial cell wall-DNA complex in the treatment of carcinoma in situ of the bladder after standard intravesical therapy has failed. J Urol. 2009;181: 1040-1045.

15. Morales A. Evolution of intravesical immunotherapy for bladder cancer: mycobacterial cell wall preparation as a promising agent. Expert Opin Investig Drugs. 2008;17: 1067-1073.

16. Morales A, Chin JL, Ramsey EW. Mycobacterial cell wall extract for treatment of carcinoma in situ of the bladder. J Urol. 2001;166: 1633-1637; discussion 1637-1638. 
17. Chin JL, Kadhim SA, Batislam E, Karlik SJ, Garcia BM, Nickel JC, Morales A. Mycobacterium cell wall: an alternative to intravesical bacillus Calmette Guerin (BCG) therapy in orthotopic murine bladder cancer. J Urol. 1996;156: 1189-1193.

18. Alkemade. SJ, Buckley TC, McRae. G. Immunostimulatory bacterial cell wall fraction. In: USPTO, editor. Unated States of America: Vetrepharm, Inc, 1998.

19. Filion MC, Phillips NC. Therapeutic potential of mycobacterial cell wall-DNA complexes. Expert Opin Investig Drugs. 2001;10: 2157-2165.

20. Rodrigues L, Masic A. Mycobacterium Cell Wall Fraction (Immunocidin ${ }^{\circledR}$ ) for Canine Transitional Cell Carcinoma Treatment. Veterinary Cancer Society Conference 2015. Tysons, VA, 2015:29.

21. Mosmann T. Rapid colorimetric assay for cellular growth and survival: application to proliferation and cytotoxicity assays. J Immunol Methods. 1983;65: 55-63.

22. Veterinary cooperative oncology group - common terminology criteria for adverse events (VCOG-CTCAE) following chemotherapy or biological antineoplastic therapy in dogs and cats v1.1. Vet Comp Oncol. 2011.

23. McMillan SK, Boria P, Moore GE, Widmer WR, Bonney PL, Knapp DW. Antitumor effects of deracoxib treatment in 26 dogs with transitional cell carcinoma of the urinary bladder. J Am Vet Med Assoc. 2011;239: 1084-1089.

24. Lynch S, Savary-Bataille K, Leeuw B, Argyle DJ. Development of a questionnaire assessing health-related quality-of-life in dogs and cats with cancer. Vet Comp Oncol. 2011;9: 172182.

25. Naughton JF, Widmer WR, Constable PD, Knapp DW. Accuracy of three-dimensional and two-dimensional ultrasonography for measurement of tumor volume in dogs with transitional cell carcinoma of the urinary bladder. Am J Vet Res. 2012;73: 1919-1924.

26. Nguyen SM, Thamm DH, Vail DM, London CA. Response evaluation criteria for solid tumours in dogs (v1.0): a Veterinary Cooperative Oncology Group (VCOG) consensus document. Vet Comp Oncol. 2013.

27. D. W. Knapp BF, M. C. Filion and N. C. Phillips. Antitumor activity of mycobacterial cell wall-DNA complex (MCC) against canine urinary bladder transitional cell carcinoma cells. Veterinary Cancer Society Annual Conference Kansas City. Kansas City Missouri, , : Blackwell Publishing Ltd, 2004:46-47.

28. Azuma I, Taniyama T, Hirao F, Yamamura Y. Antitumor activity of cell-wall skeletons and peptidoglycolipids of mycobacteria and related microorganisms in mice and rabbits. Gan. 1974;65: 493-505.

29. Filion MC, Lepicier P, Morales A, Phillips NC. Mycobacterium phlei cell wall complex directly induces apoptosis in human bladder cancer cells. Br J Cancer. 1999;79: 229-235.

30. Fumuso EA, Aguilar J, Giguere S, Rivulgo M, Wade J, Rogan D. Immune parameters in mares resistant and susceptible to persistent post-breeding endometritis: effects of immunomodulation. Vet Immunol Immunopathol. 2007;118: 30-39.

31. Reader S, Menard S, Filion B, Filion MC, Phillips NC. Pro-apoptotic and immunomodulatory activity of a mycobacterial cell wall-DNA complex towards LNCaP prostate cancer cells. Prostate. 2001;49: 155-165.

32. Yamanaka K, Hara I, Nagai H, Miyake H, Gohji K, Micallef MJ, Kurimoto M, Arakawa $\mathrm{S}$, Kamidono S. Synergistic antitumor effects of interleukin-12 gene transfer and systemic administration of interleukin-18 in a mouse bladder cancer model. Cancer Immunol Immunother. 1999;48: 297-302. 
33. Filion MC, Filion B, Reader S, Menard S, Phillips NC. Modulation of interleukin-12 synthesis by DNA lacking the CPG motif and present in a mycobacterial cell wall complex. Cancer Immunol Immunother. 2000;49: 325-334.

34. Knapp DW, Richardson RC, Chan TC, Bottoms GD, Widmer WR, DeNicola DB, Teclaw R, Bonney PL, Kuczek T. Piroxicam therapy in 34 dogs with transitional cell carcinoma of the urinary bladder. J Vet Intern Med. 1994;8: 273-278.

\title{
IN VITRO I IN VIVO ANTI-TUMORSKI POTENCIJAL FRAKCIJA MIKOBATERIJSKOG ĆELIJSKOG ZIDA U TRETMANU TRANZICIONOG ĆELIJSKOG KARCINOMA MOKRAĆNE BEŠIKE KOD PASA
}

\author{
FILION C Mario, RODRIGUES Lucas, JOHANNES Chad, MASIC Aleksandar
}

Tranzicioni ćelijski karcinom (TCC) je najčešći oblik karcinoma mokraćne bešike kod pasa i predstavlja 2\% od ukupnog broja karcinoma pasa. TCC kod pasa se obično javlja kao visoko-invazivni karcinom i najčešći problemi povezani sa TCC uključuju opstrukcije urinarnog trakta i udaljene metastaze kod više od 50\% obolelih pasa. TCC je lokalizovan u regionu bešike koji isključuje kompletnu hiruršku resekciju. Trenutne terapijske opcije za TCC kod pasa uključuju terapiju lekovima, hirurgiju ili zračenje. Mikobakterijske frakcije ćelijskog zida su biološki imunomodulatori poreklom od nepatogenog Mycobacterium phlei. Poseduju potencijal za širu primenu u terapiji karcinoma, palijativnoj nezi i lečenju zaraznih bolesti kod malih i velikih životinja. Smatra se da osim što indukuju apoptozu tumorskih ćelija još i stimulišu ćelije imunskog sistema na sintezu i lučenje citokina i hemokina. $\mathrm{U}$ ovom radu iznose se rezultati iz in vitro $\mathrm{i}$ in vivo ogleda koji mogu podržati upotrebu MFĆZ -a kao dodatne opcije u lečenju TCC kod pasa. Od posebnog značaja je dokaz da MFĆZ indukuje inhibiciju proliferacije K9TCC ćelija što je povezano sa indukcijom apoptoze, merenom pomoću proteolitičke aktivacije kaspaze-3 i degradacije PARP. Takođe, predstavljena je bezbednost i efektivni potencijal za in vivo upotrebu MFĆZ u terapiji pasa sa stadijumom T2 TCC, što se manifestuje smanjenjem kliničkih znakova i poboljšanjem kvaliteta života kod pasa obolelih od TCC. 